Tropical Journal of Pharmaceutical Research February 2017; 16 (2): 305-311

ISSN: $1596-5996$ (print); 1596-9827 (electronic) (C) Pharmacotherapy Group, Faculty of Pharmacy, University of Benin, Benin City, 300001 Nigeria.

\title{
Physicochemical properties and lubricant potentials of Blighia sapida Sapindaceaeae seed oil in solid dosage formulations
}

\author{
Sinmisola Aloko ${ }^{1}$, Chukwuemeka P Azubuike ${ }^{1 \star}$ and Herbert AB Coker ${ }^{2}$ \\ ${ }_{1}^{1}$ Department of Pharmaceutics and Pharmaceutical Technology, ${ }^{2}$ Department of Pharmaceutical Chemistry, Faculty of \\ Pharmacy, College of Medicine Campus, University of Lagos, PMB 12003, Lagos, Nigeria \\ *For correspondence: Email: cazubuike@unilag.edu.ng; Tel: +234-8033618556
}

\begin{abstract}
Purpose: To investigate and compare the physicochemical properties and lubricant potentials of Blighia sapida seed oil (BSSO) with those of magnesium stearate, a commercial lubricant.

Methods: The dried seeds of Blighia sapida (BS) powder were macerated with $n$-hexane for five days to separate the oil. The physicochemical properties; solubility profile, acid value, saponification value, iodine value of the oil were determined using standard methods. Batches of ascorbic acid tablets compressed at same compression settings using different concentrations of BSSO as lubricant were evaluated for their friability, weight uniformity, tablet hardness, disintegration and dissolution.

Results: BSSO had a density of $0.9 \mathrm{~g} / \mathrm{ml}$, acid value of $2.65 \pm 0.20 \mathrm{mg} \mathrm{KOH} / \mathrm{g}$, saponification value of $141.65 \pm 0.75 \mathrm{mg} \mathrm{KOH} / \mathrm{g}$, iodine value of $62.50 \pm 3.71 \mathrm{mg} \mathrm{l} / \mathrm{g}$ among other parameters. Fatty acid methyl ester analysis (FAME) revealed $96.89 \%$ of monounsaturated fatty acids and esters in the range of $\mathrm{C}_{15}-\mathrm{C}_{23}$; a $\mathrm{C}_{23}$ compound, 22-tricosenoic acid was the dominant compound (46.82\%). The oil showed excellent lubrication properties in ascorbic acid tablets at a low concentration (0.5\%), similar to $2 \%$ magnesium stearate. However, higher concentration (5\%) of BSSO resulted in granules that could not be compressed into tablets. Tablets containing BSSO demonstrated satisfactory friability, weight uniformity, hardness, disintegration and dissolution characteristics.

Conclusion: Blighia sapida seed oil is a potentially useful low-cost tablet lubricant. However, further investigations on the excipient, including stability, toxicity, etc, are required to ascertain its suitability.
\end{abstract}

Keywords: Blighia sapida, Lubricants, Seed oil, Excipients, Ascorbic acid, Tablet properties, 22Tricosenoic acid

Tropical Journal of Pharmaceutical Research is indexed by Science Citation Index (SciSearch), Scopus, International Pharmaceutical Abstract, Chemical Abstracts, Embase, Index Copernicus, EBSCO, African Index Medicus, JournalSeek, Journal Citation Reports/Science Edition, Directory of Open Access Journals (DOAJ), African Journal Online, Bioline International, Open-J-Gate and Pharmacy Abstracts

\section{INTRODUCTION}

Plant materials are major source of low-cost and novel excipients. These materials can be tailored for many applications, since they can be modified to achieve new materials with various physicochemical and functional properties. The search for under-utilized, novel, and renewable materials as sources of low cost excipients for pharmaceutical industry has been a major focus for research $[1,2]$.

Excipients are essential for manufacturing and administration of the dosage form and also help in stability and bioavailability of the active drug [3]. Exploring local sources of low-cost substitutes could lead to the discovery of excipients with outstanding properties [4]. Products derived from plants sources can be 
used as binders, disintegrants, diluents, vehicles, lubricants in formulation of different dosage forms.

Lubricants improve powder processing by reducing or preventing friction, heat and wear. The fundamental principles of lubrication in terms mechanisms of action in pharmaceutical processes have been well documented [5]. In terms of their chemical structure, commonly used lubricants for boundary lubrication include;- long chain molecules with active end-groups such as $-\mathrm{NH}_{2}$ (long chain amine); $-\mathrm{OH}$ (long chain alcohol); $-\mathrm{COOH}$ (long chain fatty acids); and metal ions such as $\mathrm{Mg}^{2+}[6]$.

Blighia sapida (Ackee) is a fruit tree which originates from West Africa [7]. The fruit when matured is noted for its food, medicinal and aesthetic values [8]. The black shiny seeds revealed after ripening are usually thrown away in most places. Djenontin et al [9] reported that the BSSO contains monounsaturated and saturated fatty acids. Blighia sapida seeds are practically thrown away most times after consumption of the fruit aril. However, efficient utilization of the seed oil as lubricant would require adequate information on its characteristics, functional, physicochemical and even storage properties.

To the best of our knowledge, there is no report available on the use of BSSO as a pharmaceutical lubricant. This work was aimed at investigating the lubricant potentials of BSSO and its possible application as a novel, effective and low-cost alternative lubricant in solid dosage formulations.

\section{EXPERIMENTAL}

\section{Materials}

Ascorbic acid powder, maize starch, magnesium stearate, sodium starch glycolate and talc were gifts from Ecomed Pharma Ltd, Ota, Ogun State, Nigeria. All other chemicals and solvents used were of analytical grade and were manufactured by BDH Chemicals, Poole, England.

\section{Plant collection and extraction of seed oil}

The dried seeds of Blighia sapida were collected in August 2015 from local farmers in Ogbomosho, Nigeria. They were identified and authenticated by Mr. O.O. Oyebanji of the Department of Botany, University of Lagos, Nigeria and given the voucher number LUH 6709 . The specimen sample was deposited in Department of Botany, University of Lagos herbarium for future reference. The seed coats were removed manually by peeling with knives and dried at $40{ }^{\circ} \mathrm{C}$ for 48 hours. The dried seeds were milled and screened through a mesh with a sieve aperture of $0.5 \mathrm{~mm}$. The resulting powder was packed in a sealed polyethylene bags and stored at room temperature until use. Two kilograms of the powder was macerated using $n$ hexane for 5 days. The oil was thereafter separated and stored at $4 \stackrel{\circ}{\circ}[9]$.

\section{Physicochemical characterisation of Blighia sapida seed oil}

The macroscopic and organoleptic properties of the Ackee seed oil were evaluated; appearance, colour, odour, flavour were examined and documented. The oil was also evaluated for solubility in water, ether, acetone, benzene, chloroform and ethanol in accordance with standard protocols [10].

For the determination of acid, saponification, iodine and peroxide values of BSSO, standard methods were employed [11].

\section{Fatty acid methyl ester (FAME) analysis of Blighia sapida seed oil}

The BSSO fatty acid methyl ester (FAME) analysis was carried out using Gas Chromatography-Mass Spectrometry (GCMS) (GCMS-QP2010 Plus Shimadzu, Japan) column oven: $50{ }^{\circ} \mathrm{C}$, injection volume: $1 \mu \mathrm{l}$, injection mode: split 2:1. Column oven temperature programme: $50{ }^{\circ} \mathrm{C}$ held for 2 minutes, at 7 ${ }^{\circ} \mathrm{C} / \mathrm{min}$, increased to $280{ }^{\circ} \mathrm{C}$, then held for 2 minutes. Column specifications: Rtx-5MS, 30 $\mathrm{mm}$ by $0.25 \mu \mathrm{m}$ by $0.25 \mathrm{~mm}$. Ion source temperature: $230{ }^{\circ} \mathrm{C}$, interface temperature: 250 ${ }^{\circ} \mathrm{C}$, solvent cut time: 2.5 mins. MS programme: start time- 4 minutes, end time- 35.35 minutes, $\mathrm{m} / \mathrm{z}$ (mass recharge ratio) scan: $35-600$, scan speed: 2000. The solid oil sample was heated to its liquid oil state and dissolved in n-hexane. The dissolved oil was then injected into the GCMS apparatus.

\section{Formulation of ascorbic acid granules and tablets}

Six batches of granules containing ascorbic acid (Table 1) were prepared using wet granulation method; batch A1 as reference standard containing magnesium stearate as lubricant while batches $A 2$ to $A 6$ containing various concentrations of the seed oil as lubricant. Each batch was prepared by sieving the required amounts of the bulking agent (maize starch) and ascorbic acid into a clean bowl and mixed 
intimately. Sufficient quantity of the binder (2\% $\mathrm{w} / \mathrm{v}$ maize starch mucilage) was added to the dry powders and mixed to form a wet mass. The wet mass was dried in a tray drier at $50{ }^{\circ} \mathrm{C}$ for an hour in an oven (RDTD-48, RidhiPharma, India) and then sieved through an American Standard Sieve No 16. The resulting granules were further dried for about 12 hours. The disintegrant (4\% $\mathrm{w} / \mathrm{w}$ sodium starch glycolate) and glidant (4\% $\mathrm{w} / \mathrm{w}$ talcum) were added and mixed with the granules for 5 minutes before mixing with the lubricant for 2 minutes.

The granules prepared were evaluated for their flow properties and then compacted using a rotary press (Double Rotary Press, Cadmach Ahmebad-B, India) at the same compression settings. However, batch A6 containing $5 \%$ BSSO as lubricant could not be compressed into tablets at the same compression settings as other batches.

\section{Evaluation of ascorbic acid tablets}

The weight uniformity, tablet thickness, tablet hardness, tablet friability and disintegration times of the different ascorbic acid formulations were determined using the methods reported in a previous study [12].

The average weight of each batch was determined by weighing individually and collectively on a digital weighing balance (Contech CB series, Greifensee, Switzerland) twenty tablets that were randomly selected. The deviation of each of the individual tablets in each batch from the average weight of the sample was determined. The percentage deviation was also calculated.

The thicknesses of ten tablets were evaluated using a calliper (Mitoyo Digimatic calliper-Mitoyo Japan), the mean and standard deviation and the confidence interval was then computed.

For hardness test, ten tablets were randomly selected and the force required to crush each of them was determined using a hardness tester (Mosanto, Dolphin TM, Mumbai, India).

The friability of ten randomly selected tablets was determined for each batch in a friabilator (ET-2 model, Electrolab, India). The drum was rotated at 25 rotations per minute (rpm) for 4 minutes. Loss of tablet weight with respect to the initial weight was then calculated after the tablets were re-dusted, weighed and observed for capping and lamination.

Disintegration time for six randomly selected tablets from each batch was determined using a USP disintegration tester (model ED-2AL, Electrolab, Mumbai, India). The apparatus was operated using distilled water as the medium and immersion fluid, the set up was maintained at 37 $\pm 2{ }^{\circ} \mathrm{C}$. One tablet was placed in each of the six tubes of the disintegration basket. The time taken for all tablet particles in each unit to pass through the mesh was recorded.

Dissolution test was carried out using the method stated in the USP [13]. Drug release was determined using a USP dissolution tester (TDT 08L, Dissolution tester, Electrolab, Mumbai, India) the paddle type. The dissolution medium used was $900 \mathrm{~mL}$ of distilled water at $50 \mathrm{rpm}$ paddle speed. The apparatus ran for 45 minutes, after which $20 \mathrm{~mL}$ of each sample was withdrawn and filtered. It was immediately titrated against standard dichlorophenol-indophenol VS. The end point was detected when a rose pink colour that persists for at least $5 \mathrm{sec}$ was observed. Ascorbic acid (A) content was calculated using equation 1.

$A(\%)=(v s-v b) \times F \times\left[\frac{\frac{v m}{2}}{L}\right] \times 100$

where vs is titrant volume consumed by the sample $(\mathrm{mL}), \mathrm{vb}=$ titrant volume consumed by the blank $(\mathrm{mL}), \mathrm{F}=$ factor (concentration of the titrant in terms of the equivalent of ascorbic acid $(\mathrm{mg} / \mathrm{mL}), \mathrm{VM}=$ volume of medium, $900 \mathrm{~mL}, \mathrm{a}=$ volume of the aliquot taken for analysis while $L=$ labelled amount of ascorbic acid (mg/tab).

Table 1: Composition of ascorbic acid granules/tablet formulations

\begin{tabular}{lccccccc}
\hline Batch & $\begin{array}{l}\text { Ascorbic } \\
\text { acid (\%) }\end{array}$ & $\begin{array}{l}\text { Maize starch } \\
\text { paste (\%) }\end{array}$ & $\begin{array}{l}\text { BSSO } \\
(\%)\end{array}$ & $\begin{array}{l}\text { Magnesium } \\
\text { Stearate (\%) }\end{array}$ & $\begin{array}{l}\text { Sodium starch } \\
\text { glycolate (\%) }\end{array}$ & $\begin{array}{l}\text { Talcum } \\
(\%)\end{array}$ & $\begin{array}{l}\text { Maize } \\
\text { starch to } \\
(\%)\end{array}$ \\
\hline A1 & 5 & 2 & 0 & 2 & 4 & 4 & 100 \\
A2 & 5 & 2 & 0.5 & 0 & 4 & 4 & 100 \\
A3 & 5 & 2 & 1 & 0 & 4 & 4 & 100 \\
A4 & 5 & 2 & 2 & 0 & 4 & 4 & 100 \\
A5 & 5 & 2 & 4 & 0 & 4 & 4 & 100 \\
A6 & 5 & 2 & 5 & 0 & & 4 & 4 \\
\hline
\end{tabular}




\section{Statistical analysis}

The data emanating from the study was analyzed using OriginPro 2016 (64-bit) software (OriginLab Corporation Northampton, MA 01060 USA). Mean comparison with the standard was evaluated using one-way analysis of variance (ANOVA) at $95 \%$ confidence level $(p<0.05)$. Significant differences of mean values were determined by Tukey test.

\section{RESULTS}

Percentage yield, organoleptic properties and solubility of Blighia sapida seed oil

The percentage yield of the oil was $12.5 \%$. The oil had a faint sweet smell and was soluble in benzene and chloroform but insoluble in ethanol and water.

\section{Physicochemical properties of Blighia sapida seed oil}

The chemical properties of BSSO are presented in Table 2. Acid value of BSSO obtained was $2.65 \mathrm{mg} \mathrm{KOH} / \mathrm{g}$ while the saponification value was $141.65 \mathrm{mg} \mathrm{KOH} / \mathrm{g}$. Blighia sapida seed oil had iodine value $\left(\mathrm{mgl}_{2} / \mathrm{g}\right)$ of 62.50 while a peroxide value of $8.68 \mathrm{mg}$ reactive $\mathrm{O}_{2} \mathrm{~g}^{-1}$ was obtained for the oil.

Table 2: Physicochemical properties of Blighia sapida seed oil $( \pm S D, n=3)$

\begin{tabular}{lc}
\hline Parameter & Value \\
\hline Acid $(\mathrm{mg} \mathrm{KOH} / \mathrm{g})$ & $2.65 \pm 0.20$ \\
Saponification $(\mathrm{mg} \mathrm{KOH} / \mathrm{g})$ & $141.65 \pm 0.7$ \\
& 5 \\
lodine $\left(\mathrm{mg} \mathrm{I}_{2} / \mathrm{g}\right)$ & $62.50 \pm 3.71$ \\
Ester $(\mathrm{mg} \mathrm{KOH} / \mathrm{g})$ & $139.00 \pm 0.0$ \\
& 0 \\
Peroxide $\left(\mathrm{mg}\right.$ reactive $\left.\mathrm{O}_{2} \mathrm{~g}^{-1}\right)$ & $8.68 \pm 4.20$ \\
Density $(\mathrm{g} / \mathrm{mL})$ & 0.90 \\
\hline
\end{tabular}

Table 3: Fatty acid methyl ester composition of Blighia sapida seed oil

\begin{tabular}{lcc}
\hline Compound & Formula & $\begin{array}{c}\text { Content } \\
\text { (\%) }\end{array}$ \\
\hline n-Hexadecanoic acid & $\mathrm{C}_{16} \mathrm{H}_{32} \mathrm{O}_{2}$ & 1.17 \\
Ethyl tridecanoate & $\mathrm{C}_{15} \mathrm{H}_{30} \mathrm{O}_{2}$ & 0.30 \\
11-Octadecenoic acid, & $\mathrm{C}_{20} \mathrm{H}_{40} \mathrm{O}_{2}$ & 0.58 \\
methyl ester & & \\
Ethyl Oleate & $\mathrm{C}_{20} \mathrm{H}_{38} \mathrm{O}_{2}$ & 23.49 \\
Oleic acid & $\mathrm{C}_{18} \mathrm{H}_{34} \mathrm{O}_{2}$ & 16.76 \\
$\begin{array}{l}\text { Octadecanoic acid,2-(2- } \\
\text { hydroxyethoxy)ethyl ester }\end{array}$ & $\mathrm{C}_{18} \mathrm{H}_{34} \mathrm{O}_{2}$ & 4.63 \\
$\begin{array}{l}\text { Cis-11-Eicosanoic, methyl } \\
\text { ester }\end{array}$ & $\mathrm{C}_{21} \mathrm{H}_{40} \mathrm{O}_{2}$ & 5.19 \\
Eicosanoic acid, methyl & $\mathrm{C}_{21} \mathrm{H}_{42} \mathrm{O}_{2}$ & 1.06 \\
ester & & \\
22-Tricosenoic acid & $\mathrm{C}_{23} \mathrm{H}_{44} \mathrm{O}_{2}$ & 46.82 \\
Total & & $\mathbf{1 0 0}$ \\
\hline
\end{tabular}

Fatty acid methyl ester composition of Blighia sapida seed oil

Fatty acid methyl ester analysis of BSSO revealed a range of fatty acids from $\mathrm{C}_{15}-\mathrm{C}_{23}$ (Table 3). The BSSO contained predominantly monounsaturated and saturated fatty acids and also straight chain hydrocarbons and aromatic compound.

\section{Properties of ascorbic acid granules and tablets}

The properties of the ascorbic acid granules (Table 4) showed that the Hausner's ratios of the granules containing different concentrations of the oil gave values (1.00-1.04) that were less than 1.15 while the values of compressibility index (\%) varied from 0.34 to 11.59 . The lowest concentration of the seed oil $(0.5 \%)$ had lowest Hausner's ratio (1.00) and compressibility index $(0.34 \%)$ while the highest concentration of the seed oil (5\%) had highest Hausner's ratio (1.13) and compressibility index (11.59\%). Batch A2 granules containing $0.5 \% \mathrm{BSSO}$ had

Table 4: Physical properties of ascorbic acid granules $( \pm S D, n=3)$

\begin{tabular}{lcrcc}
\hline Batch & $\begin{array}{c}\text { Tapped } \\
\text { density }(\mathbf{g} / \mathbf{m l})\end{array}$ & $\begin{array}{c}\text { Bulk } \\
\text { density(g/ml) }\end{array}$ & $\begin{array}{c}\text { Hausner's } \\
\text { ratio }\end{array}$ & $\begin{array}{c}\text { Compressibility } \\
\text { index (\%) }\end{array}$ \\
\hline A1 & $0.67 \pm 0.02$ & $0.65 \pm 0.03$ & 1.04 & 3.73 \\
A2 & $0.59 \pm 0.05$ & $0.59 \pm 0.08$ & 1.00 & 0.34 \\
A3 & $0.65 \pm 0.09$ & $0.64 \pm 0.06$ & 1.02 & 2.32 \\
A4 & $0.65 \pm 0.07$ & $0.63 \pm 0.11$ & 1.03 & 3.01 \\
A5 & $0.65 \pm 0.10$ & $0.63 \pm 0.08$ & 1.04 & 3.85 \\
A6 & $0.69 \pm 0.12$ & $0.61 \pm 0.09$ & 1.13 & 11.59 \\
\hline
\end{tabular}

Lubricant concentration of the granules: A1;Magnesium stearate $2 \%, A 2 ; B S S O$ 0.5\%, A3;BSSO 1\%, A4;BSSO $2 \%$, A5; BSSO 4\%, A6 ;BSSO 5\% 
Table 5: Properties of formulated ascorbic acid tablets

\begin{tabular}{lccccc}
\hline Parameter & A1 & A2 & A3 & A4 & A5 \\
\hline Mean weight $(\mathrm{mg})$ & $354 \pm 4$ & $359 \pm 4$ & $351 \pm 4$ & $353 \pm 4$ & $356 \pm 4$ \\
Tablet thickness $(\mathrm{mm})$ & $4.0 \pm 0.2$ & $4.0 \pm 0.2$ & $4.0 \pm 0.2$ & $4.0 \pm 0.2$ & $4.0 \pm 0.2$ \\
Crushing strength (kgf) & 3 & 3 & 2 & 2 & 1 \\
Disintegration time (min) & $2.5 \pm 0.3$ & $2.5 \pm 0.5$ & $1.8 \pm 0.2$ & $1.3 \pm 0.6$ & $2.3 \pm 0.8$ \\
Dissolution (t 45 mins)(\%) & 85 & 85 & 85 & 85 & 85 \\
\hline
\end{tabular}

Lubricant concentration of the formulations:A1;Magnesium stearate 2\%, A2;BSSO 0.5\%, A3;BSSO $1 \%$, A4;BSSO 2\%, A5;BSSO 4\%, A6; BSSO 5\%); A6 could not be compressed into tablets at the same compression settings with other batches

significantly lower compressibility index and Hausner's ratio compared to the batch A1 containing $2 \%$ magnesium stearate. Compressibility index values increased significantly $(p<0.05)$ from 2 to $5 \%$ concentration of the oil.

The properties of the formulated ascorbic acid tablets are presented in Table 5 . All batches (A1 to A5) passed the weight uniformity test. The results obtained for hardness test showed that there was no significant difference between formulations $\mathrm{A} 1$ containing $2 \%$ magnesium stearate and A2 containing $0.5 \%$ BSSO. Formulation A5 containing $4 \%$ BSSO as lubricant had the least crushing strength (Table $5)$.

The results of the disintegration time (Table 5) showed that $A 1$ and $A 2$ had the same disintegration time (2.5 minutes) while A4 had the least (1.3 minutes). $0.5 \%$ of BSSO gave the same disintegration time (2.5 minutes) as $2 \%$ of magnesium stearate. The dissolution test indicated that all the formulated ascorbic acid tablets released $85 \%$ of the drug content at 45 minutes.

\section{DISCUSSION}

The low yield of the oil (12.5\%) compared to those recorded in previous studies; $21.6 \%$ [9], $15.61 \%$ [14], $21.0 \%$ [15] might be attributed to various factors such as the differences in the genetic make-up of the plants, maturity of the plant at time of collection and place of collection of the plant materials [16], and also mode of extraction employed in the different studies. Hence, there is need for optimization of extraction process prior to large scale seed valorization.

The good flavor and faint sweet pleasant smell of the seed oil are desirable in materials to be used as excipients in the pharmaceutical industry so as to ensure good appeal to the patient and to encourage compliance.
Acid value is a measure of the free fatty acids (FFA) present in the oil. The lower the acid value of oil, the fewer free fatty acids it contains which makes it less exposed to rancidity $[14,16]$. Acid value could also be used to check the level of oxidative deterioration of oil by enzymatic or chemical oxidation. The acid value $(2.65 \mathrm{mg}$ $\mathrm{KOH} / \mathrm{g}$ ) obtained for the BSSO was lower than those reported in earlier studies (39.49 $\mathrm{mgKOH} / \mathrm{g}, 14.2 \mathrm{mg} \mathrm{KOH} / \mathrm{g})[14,18]$ but was similar to that of beniseed oil $((2.77 \mathrm{mg} \mathrm{KOH} / \mathrm{g}$ and $2.74 \mathrm{mg} \mathrm{KOH} / \mathrm{g}$ ) [19]. The lower acid value of BSSO mighty be an advantage in terms of stability when used in formulations. The low acid value reported for BSSO might be attributed to the absence of polyunsaturated FAs in the oil.

The saponification value $(141.65 \mathrm{mg} \mathrm{KOH} / \mathrm{g}$ ) of the BSSO reported in the study was similar to the value $(145.0 \mathrm{mg} \mathrm{KOH} / \mathrm{g})$ reported by Djenontin et al [9]. Saponification value determines the quantity of potassium hydroxide (in $\mathrm{mg}$ ) needed to neutralize the acids and saponify the esters contained in $1 \mathrm{~g}$ of the lipid [17]. The higher the saponification value of an oil, the higher the lauric acid content and the better the suitability in soap and shampoo formulations. Hence, BSSO could be a good ingredient for soap and shampoo formulations.

lodine value $\left(\mathrm{mgl}_{2} / \mathrm{g}\right)$ of 62.50 obtained for BSSO was similar to those reported in earlier studies; 66.0 [9], 65.4 [20] and 65.0 [21] but higher than that reported by Onuekwusi et al [14]. Iodine value measures the degree of unsaturation in a fat or vegetable oil. The value showed that BSSO contained a reasonable amount of carbon-carbon double bonds.

BSSO peroxide value of $8.68 \mathrm{mg}$ reactive $\mathrm{O}_{2} \mathrm{~g}^{-1}$ is within WHO/FAO stipulated maximum peroxide level of not more than $10 \mathrm{M}$ equivalent of peroxide oxygen $/ \mathrm{Kg}$ for food oils [17]. Hence, BSSO might be considered safe for oral consumption.

The fat acid methyl ester composition of Blighia sapida oil obtained from different sources by different authors had been reported $[9,14,15]$ and 
some differed significantly. The main features of FAME analysis of BSSO obtained in this study were its content of $\mathrm{FAs}$ in the $\mathrm{C}_{23}$ range; which accounted for $46.82 \mathrm{wt} \%$, followed by the $\mathrm{C}_{20}$ range; $24.07 \mathrm{wt} \%$, then the $\mathrm{C}_{18}$ range; 21.39 $w t \%$. Djenontin et al [9] reported $63.6 \mathrm{wt} \%$ monounsaturated fatty acids, while this study revealed $73.4 \mathrm{wt} \%$ of monounsaturated fatty acid and 23.49 wt\% of monounsaturated oleic acid ethyl ester-ethyl oleate; only $3.11 \%$ of saturated fatty acids were present and no polyunsaturated compounds was present. Owing to the high concentration of monounsaturated fatty acids and absence of polyunsaturated compounds, the seed oil would be expected to be stable against oxidation hence formulations containing BSSO would be more stable compared to those with polyunsaturated FAs content. Oleic acid found in significant amount in the seed oil is an omega-9fatty acid with very good food, medicinal and health benefits. Ethyl oleate, which is the more lipid soluble form of oleic acid, is widely used as a solvent for steroids. Thus, BSSO could be used as food, surfactant, lubricant etc. The lubricant effect stemming from the carboxylic acid groups present since boundary lubrication could be achieved by employing long chain molecules (long chain fatty acids) with active $-\mathrm{COOH}$ endgroups [6].

The four batches formulated using Blighia sapida seed oil as lubricant as well as A1 containing $2 \%$ magnesium stearate passed the weight uniformity test (Table 3). The BP [10] specified that for a tablet with $350 \mathrm{mg}$ weight, the weight variation must be within $\pm 5 \%$. One of the reasons for this observation might be attributed to lubricants employed in the formulations which contributed to improved flow properties of the granules and also uniform filling of the die cavity. However, batch A6 granules could not be compressed into tablets as it was not cohesive. This might be attributed to the high concentration of BSSO (5\%), the lubricant. Over lubrication might interfere with the bonding of particles resulting in weak tablets [22].

For hardness, 0.5 wt\% gave tablets with $3 \mathrm{kgf}$ hardness, subsequent batches gave lesser values, which implies that the higher the concentration of BSSO as lubricant, the softer the tablets become. It can be deduced that BSSO $0.5 \mathrm{wt} \%$ gave the best result compared to magnesium stearate regarding tablet hardness. BSSO $(0.5 \%)$ gave the same disintegration time (2.5 $\mathrm{min})$ as $2 \%$ of magnesium stearate. The disintegration time showed a decrease with increasing concentration of BSSO until the $4 \%$ concentration where hydrophobicity effect of the oil had set in, generally, all the tablets passed the disintegration test which is specified to be not more than 15 minutes [10]. Lubricants generally have a strong negative effect on the water uptake if tablets contain no disintegrants. If a strong disintegrant is present (e.g., sodium starch glycolate used in this study), disintegration time is rarely affected. Sodium starch glycolate has been reported to be unaffected by the presence of hydrophobic lubricants unlike other disintegrants [23].

For most dosage forms to be efficacious, the active pharmaceutical ingredient (API) must be absorbed into the systemic circulation so that it can be transported to its site of activity. A1 to A5 batches of ascorbic acid tablets all released 85 $\%$ of the drug at 45 min therefore complying with the compendia requirement [13]. This observation implies that there was noninterference of BSSO with the dissolution profile of the ascorbic acid tablets.

\section{CONCLUSION}

Blighia sapida seed oil (BSSO) with some desired functional and physicochemical properties has been successfully from Blighia sapida seeds. The findings of this study show that BSSO compares favourably with the wellknown magnesium stearate as a tablet lubricant, and therefore, has a potential for use as a lowcost lubricant in solid dosage form manufacture. However, further investigations on the excipient, including stability, toxicity, etc, are required to fully ascertain its suitability.

\section{DECLARATIONS}

\section{Acknowledgement}

The authors are grateful to Ecomed Pharma Ltd for providing laboratory facilities for the work as well as some of the pharmaceutical raw materials used.

\section{Conflict of Interest}

No conflict of interest associated with this work.

\section{Contribution of Authors}

The authors declare that this work was done by the authors named in this article and all liabilities pertaining to claims relating to the content of this article will be borne by them.

\section{Open Access}

This is an Open Access article that uses a 
funding model which does not charge readers or their institutions for access and distributed under the terms of the Creative Commons Attribution License (http://creativecommons.org/licenses/by 14.0) and the Budapest Open Access Initiative (http://www.budapestopenaccessinitiative.org/rea d), which permit unrestricted use, distribution, and reproduction in any medium, provided the original work is properly credited.

\section{REFERENCES}

1. Ashogbon AO, Akintayo ET. Recent trend in the physical and chemical modification of starches from different botanical sources: A review. Starch-Stärke 2014; 66(12): 41-57.

2. Al-Khattawi A, lyire A, Dennison $T$, Dahmash $E, J$ Bailey $C$, Smith J, Rue $P, R$ Mohammed A. Systematic screening of compressed ODT excipients: cellulosic versus non-cellulosic. Curr Drug Deliv 2014; 11(4):486500.

3. Pifferi G, Restani, $P$. The safety of pharmaceutical excipients. II Farmaco 2003; 58(8): 541-550.

4. Azubuike CP, Okhamafe AO. Physicochemical, spectroscopic and thermal properties of microcrystalline cellulose derived from corn cobs. Int $J$ Recycl Org Waste Agric 2012; 1(1): 9.

5. Li J, Wu Y. Lubricants in pharmaceutical solid dosage forms. Lubricants 2014; 2(1): 21-43.

6. Derle ND, Derle DV, Bele MH, Khatale SB. Functionality testing of excipients: A Review. Int J Pharm Sci Res 2016; 7(8): 3208-3217.

7. Gaillard Y, Carlier J, Berscht M, Mazoyer C, Bevalot F, Guitton J, Fanton L. Fatal intoxication due to ackee (Blighia sapida) in Suriname and French Guyana. GCMS detection and quantification of hypoglycin- $A$. Forensic Sci Int 2011; 206(1): e103-e107.

8. Barceloux DG. Akee fruit and Jamaican vomiting sickness (Blighia sapida Köenig). Dis Mon. 2009; 55(6), 318-326.

9. Djenontin ST, Wotto VD, Lozano $P$, Pioch $D$, Sohounhloue DKC. Characterisation of Blighia sapida (Sapindaceae) seed oil and defatted cake from Benin. Nat Prod Res 2009; 23(6): 549-560.

10. British pharmacopeia. British Pharmacopeia. London: British Pharmacopeia commission; 2007.
11. IUPAC (1987). Section 2: Oils and fats. In C. Paquot \& A. Hautfenne (Eds.), Standatd Methods for the analysis of oilseeds, fats and derivatives (7th revised and enlarged edition). Oxford: International Union of Pure and Applied Chemistry, Blackwell Scientific Publications.

12. Azubuike CP, Oluyase SO. Physicochemical and bioequivalence studies on some brands of Levofloxacin tablets registered in Nigeria. Br J Pharm Res 2014; 4(16):1976-1987.

13. United State Pharmacopeia. United State Pharmacopeia 2009- National Formulary [USP 32-NF 27]. Rockville, Md: United State Pharmacopeia convention Inc; 2008.

14. Onuekwusi EC, Akanya HO, Evans EC. Phytochemical Constituents of Seeds of Ripe and Unripe Blighia sapida (K. Koenig) and Physicochemical Properties of the Seed Oil. Int J Pharm Sci Invent 2014; 3(9): 31-40.

15. Esuoso K. O, Odetokun SM. Proximate composition and possible industrial utilization of Blighia sapida seed and seed oils. La Riv Ital Delle sostanze Grasse 1995; 72:311-313.

16. Foster A, Malhi SS. Influence of Seeding Date and Growing Season Conditions on Forage Yield and Quality of Four Annual Crops in North eastern Saskatchewan. Commun Soil Sci Plant Anal 2013; 44 (5): 884-891.

17. Asuquo JE, Anusiem Cl, Etim E. Extraction and characterization of shea butter oil. World J Appl Sci Technol. 2010; 2: 282-288.

18. Akintayo ET, Adebayo EA, Arogundade LA. Chemical composition, physicochemical and functional properties of ackee (Blighia sapida) pulp and seed flours. Food Chem 2002; 77: 333-336.

19. Ekpa OD, Ekpe UJ. The effect of coconuts oil concentrates and air exposure to the total acidity of palm oil. Glob J Pure Appl Sci 1995; 1(1/2):51-58.

20. Akintayo ET, Adebayo EA, Arogundade LA. Assessment of dietary exposure to the natural toxin hypoglycin in ackee (Blighia sapida). Jamaican J Food Res Intern 2002; 37: 833-838.

21. Omobuwajo TO, Sanni LA, Olajide JO. Physical properties of ackee apple (Blighia sapida) seeds. J Food Eng. 2000; 45: 43-48.

22. Bolhuis GK, Smallenbroek AJ, Lerk CF. Interaction of tablet disintegrants and magnesium stearate during mixing I: Effect on tablet disintegration. J Pharm Sci 1981; 70(12):1328-1330. 